\title{
Revised Annotated List of Parasites from Sea Mammals Caught Off the West Coast of North America
}

\author{
$\mathrm{By}$ \\ L. MARGOLIS \\ Fisheries Research Board of Canada, Biological Station \\ Nanaimo, B.C., Canada \\ and \\ M. D. DAILEY \\ Department of Biology \\ California State College at Long Beach \\ Long Beach, California 90801
}

\begin{abstract}
Parasite-host and host-parasite lists, with supporting references, of the ecto- and endoparasites recorded from marine mammals of the North American west coast are provided. Excluding records in which the parasites have not been identified to the species level, there are known 15 trematodes, 3 cestodes, 10 nematodes, 7 acanthocephalans, 1 copepod, and 10 amphipods from 22 species of Cetacea; 8 trematodes, 10 cestodes, 12 nematodes, 8 acanthocephalans, 5 anoplurans, and 5 acarines from 8 species of Pinnipedia; and 4 trematodes, 2 cestodes, 1 nematode, 3 acanthocephalans, and 1 acarine from a single species of Carnivora.

Previously unpublished records which are included here are: Anisakis simplex from Phocoenoides dalli and Orcinus orca, British Columbia; Cyamus balaenopterae from Balaenoptera musculus, California; Cyamus erraticus from Balaena glacialis, Alaska; Cyamus scammoni from Eschrichtius gibbosus, Alaska; Antarctophthirus trichechi from Odobenus rosmarus, Alaska.
\end{abstract}

\section{INTRODUCTION}

In 1954, Margolis (1954a) published a list of parasites reported from marine mammals caught in waters off western North America (Bering Strait to Mexico). This list was compiled from the literature up to July 15, 1953. During the 17 years since the preparation of the first list there has been a marked increase in the interest in marine mammals, both as objects of research and for display purposes. The numbers of animals necropsied and parasites recovered has grown rapidly. It was considered worthwhile to bring this list up to date in order to facilitate future work in this area as well as furnish a current list of parasites to nonparasitologists working with marine mammals.

The revised list is restricted to organisms generally considered to be true parasites. Excluded are the nematode Odontobius ceti Roussel de Vauzème, 1834 and the copepod Balaenophilus unisetus Aurivillius, 1879, which live on the baleen plates of whales and are best described as commensals; the barnacles, which have a phoretic relationship with whales; and the lamprey, which is often regarded as a predator rather than a temporary parasite.

As in the original list, we have included parasites reported from Steller and California sea 
lions which have died in zoological parks or marine aquaria in New York; Maryland; Washington, D.C.; Louisiana; California; Switzerland; and Germany; as evidence indicates that in most cases the sea lions were definitely captured in western North American waters and were infected prior to capture. Information obtained since publication of the first list has led us to exclude Anisakis tridentatus Kreis, 1938 from the present list. This species was described by Kreis (1938) from material collected from the stomach and lungs of a "Eumetopias jubata Schreb." that had died in 1935 in the Zoological Gardens, Bäsel, Switzerland. According to Dr. Hans A. Kreis (personal commnication to L. Margolis, January 17, 1955), the host was probably Zalophus californianus rather than E. jubatus and was born in the Bäsel Zoological Gardens, living there until its death; its parents were imported from California. Clearly, since infection of the definitive host with anisakid nematodes is via ingestion of intermediate hosts, the sea lion must have become infected in the Bäsel Zoo through its food, rather than directly from its parents. Therefore, A. tridentatus cannot be considered as a parasite that occurs on the west coast of North America.

Tadros (1966) reported the nematode Spirocerca lupi (Rudolphi, 1809) from tumours in the aorta of a $Z$. californianus which had died in the Giza Zoo, Cairo, UAR. No information was provided on the history of this animal which would allow any speculation regarding the origin of the infection; consequently this record is not included in the list.

The present list has been compiled from the literature up to December 31, 1970. Records of parasites that have not been identified at least to the generic level are not included, except for microfilariae in the blood. Several errors in the 1954 list are corrected here. A few previously unpublished records from the files of the first author are also included.

For nomenclature of hosts we have followed Rice and Scheffer (1968). In listing synonyms of parasites we give only those names used in the literature dealing with the parasites of marine mammals from the North American west coast.

\section{PARASITE-HOST LIST}

\section{Trematoda}

Braunina cordiformis Wolf, 1903

Host: Tursiops truncatus - bottle-nosed dolphin.

Locality: California.

Recorded by: Johnston and Ridgway (1969).

Campula oblonga Cobbold, 1858

Host: Phocoena phocoena - harbour porpoise.

Location: Liver.

Locality: Washington.

Recorded by: Ching and Robinson (1959).

Cryptocotyle jejuna (Nicoll, 1907) Ransom, 1920

Host: Callorhinus ursinus - northern fur seal. Location: Intestine.

Locality: Alaska.

Recorded by: Neiland (1961); Keyes (1965).

Hadwenius nipponicus Yamaguti, 1951

Host: Phocoena phocoena - harbour porpoise.

Location: Stomach (fourth chamber).

Locality: Washington.

Recorded by: Ching and Robinson (1959).

Hadwenius seymouri Price, 1932

Syn.: Odhneriella seymouri (Price, 1932)

Skrjabin and Schulz, 1935.

Host: Delphinapterus leucas - white whale.

Location: Intestine.

Locality: Alaska.

Recorded by: Price (1932).

Remarks: Skrjabin (1944) considered Hadwenius to be a synonym of Odhneriella, but Yamaguti (1951) retained it as a valid genus and described a second species.

Lecithodesmus sp.

Hosts: Balaenoptera borealis - sei whale; Megaptera novaeangliae - humpback whale.

Location: Bile ducts.

Locality: California.

Recorded by: Rice (1963). 
Lecithodesmus goliath (van Beneden, 1858) Odhner, 1905

Host: Balaenoptera physalus - fin whale.

Location: Bile ducts.

Locality: British Columbia.

Recorded by: Margolis and Pike (1955).

Lecithodesmus spinosus Margolis and Pike, 1955

Host: Balaenoptera borealis - sei whale.

Location: Bile ducts.

Locality: British Columbia.

Recorded by: Margolis and Pike (1955).

Microphallus pirum (Afanas'ev, 1941)

Rausch, 1953

Syn.: Microphallus enhydrae Rausch and Locker, 1951.

Host: Enhydra lutris - sea otter.

Location: Intestine.

Locality: Alaska.

Recorded by: Rausch and Locker (1951);

Rausch (1953) ; Schiller (1954, 1959); Kenyon (1969).

Nasitrema attenuata Neiland, Rice and Holden, 1970

Host: Pseudorca crassidens - false killer whale.

Location: Air sinuses.

Locality: Mexico.

Recorded by: Neiland et al. (1970).

Nasitrema delphini Neiland, Rice and Holden, 1970

Host: Delphinus delphis - common dolphin. Location: Air sinuses.

Locality: California.

Recorded by: Neiland et al. (1970).

Nasitrema globicephalae Neiland, Rice and Holden, 1970

Hosts: Globicephala macrorhyncha - shortfinned pilot whale; Lagenorhynchus obliquidens - Pacific white-sided dolphin; Lissodelphis borealis - northern right-whale dolphin; Pseudorca crassidens - false killer whale.

Location: Air sinuses.

Locality: California.

Recorded by: Neiland et al. (1970).
Nasitrema lanceolata Neiland, Rice and Holden, 1970

Host: Globicephala macrorhyncha - shortfinned pilot whale.

Location: Air sinuses.

Locality: California.

Recorded by: Neiland et al. (1970).

Nasitrema stenosoma Neiland, Rice and Holden, 1970

Host: Stenella dubia - spotted dolphin.

Location: Air sinuses.

Locality: Mexico.

Recorded by: Neiland et al. (1970).

Ogmogaster antarcticus Johnston, 1931

Hosts: Balaenoptera physalus - fin whale; Eschrichtius gibbosus - gray whale.

Locations: Intestine and rectum.

Localities: British Columbia; California.

Recorded by: Rausch and Fay (1966); Rausch and Rice (1970).

Remarks: Rausch and Fay (1966) separated Ogmogaster plicatus of Margolis and Pike (1955), from the fin whale, into O. plicatus and $O$. antarcticus.

Ogmogaster pentalineatus Rausch and Fay, 1966

Host: Eschrichtius gibbosus - gray whale.

Locations: Intestine and rectum.

Localities: Alaska; California.

Recorded by: Rausch and Fay (1966) ; Rausch and Rice (1970).

Ogmogaster plicatus (Creplin, 1829) Jägerskiöld, 1891

Hosts: Balaenoptera borealis - sei whale; Balaenoptera physalus - fin whale.

Locations: Intestine and rectum.

Localities: British Columbia; California.

Recorded by: Margolis and Pike (1955); Rausch and Fay (1966); Rausch and Rice (1970).

Ogmogaster trilineatus Rausch and Rice, 1970

Host: Balaenoptera physalus - fin whale.

Location: Rectum.

Locality: California.

Recorded by: Rausch and Rice (1970). 
Orthosplanchnus arcticus Odhner, 1905

Host: Erignathus barbatus - bearded seal.

Locations: Gall bladder, bile ducts, pancreatic ducts.

Locality: Alaska.

Recorded by: Johnson et al. (1966).

Orthosplanchnus fraterculus Odhner, 1905

Hosts: Enhydralutris - sea otter; Erignathus barbatus - bearded seal.

Locations: Gall bladder, bile ducts, pancreatic ducts.

Locality: Alaska.

Recorded by: Rausch and Locker (1951); Rausch (1953); Kenyon (1969).

Phocitrema fusiforme Goto and Ozaki, 1930

Hosts: Callorhinus ursinus - northern fur seal; Enhydra lutris - sea otter; Phoca vitulina richardi - harbour seal.

Location: Intestine.

Locality: Alaska.

Recorded by: Rausch and Locker (1951); Rausch (1953); Neiland (1961); Keyes (1965).

Pricetrema zalophi (Price, 1932) Ciurea, 1933 Syn.: Apophallus zalophi Price, 1932.

Hosts: Callorhinus ursinus - northern fur seal; Enhydra lutris - sea otter; Eumetopias jubatus - Steller sea lion; Zalophus californianus - California sea lion.

Location: Intestine.

Localities: Alaska; California; Washington, D.C. (zoo).

Recorded by: Price (1932); Rausch and Locker (1951); Rausch (1953); Neiland (1961); Keyes (1965); Dailey and Hill (1970).

Remarks: Ciurea (1933) created a new genus, Pricetrema, for Apophallus zalophi Price, 1932, described from the California sea lion.

Stephanoprora denticulata (Rudolphi, 1802) Odhner, 1910

Host: Zalophus californianus - California sea lion.

Location: Intestine.

Locality: Washington, D.C. (zoo).

Recorded by: Price (1932).
Stictodora ubelakeri Dailey, 1969

Host: Zalophus californianus - California sea lion.

Location: Intestine.

Locality: California.

Recorded by: Dailey (1969); Dailey and Hill (1970).

Zalophotrema hepaticum Stunkard and Alvey, 1929

Host: Zalophus californianus - California sea lion.

Location: Liver.

Localities: California and Baja California (wild and captive animals); New York Aquarium; Washington, D.C. (zoo); Baltimore Zoo.

Recorded by: Stunkard and Alvey (1929, $1930)$; Price (1932); Schroeder and Wegeforth (1935); Fleischman and Squire (1970).

Remarks: Of several species of pinnipeds examined from Baja California and from the San Diego, Calif., Zoo, Schroeder and Wegeforth (1935) did not specify in which they found Zalophotrema hepaticum.

\section{Cestoda}

Abothrium gadi van Beneden, 1871

Host: Eumetopias jubatus - Steller sea lion. Location: Intestine.

Locality: British Columbia.

Recorded by: Margolis (1956).

Remarks: This is a typical parasite of marine fishes of the family Gadidae. It must be regarded as a pseudoparasite of the sea lion, its presence in this mammal indicating recent ingestion of a gadid.

\section{Diphyllobothrium spp.}

Hosts: Balaenoptera borealis - sei whale; Erignathus barbatus - bearded seal.

Location: Intestine.

Localities: Alaska; California.

Recorded by: Kenyon (1962); Rice (1963).

Diphyllobothrium alascense Rausch and Williamson, 1958

Host: Phoca vitulina richardi - harbour seal. Location: Intestine. 
Locality: Alaska.

Recorded by: Rausch and Hilliard (1970).

Diphyllobothrium cordatum (Leuckart, 1863)

Gedoelst, 1911

Host: Erignathus barbatus - bearded seal.

Location: Intestine.

Locality: Alaska.

Recorded by: Hilliard (1960).

Diphyllobothrium lanceolatum (Krabbe, 1865) Cooper, 1921

Hosts: Erignathus barbatus - bearded seal;

Phoca vitulina richardi - harbour seal.

Location: Intestine.

Locality: Alaska.

Recorded by: Stunkard and Schoenborn (1936); Stunkard (1948); Hilliard (1960); Rausch and Hilliard (1970).

Remarks: Wardle, McLeod, and Stewart (1947) regarded this species as identical with D. phocarum (Fabricius, 1780) and placed it in their new genus Cordicephalus. Stunkard (1948) considered Cordicephalus to be a direct synonym of Pyramicocephalus. Markowski (1952) agreed with Stunkard and Schoenborn (1936) in identifying this species from the bearded seal as $D$. lanceolatum. He replaced phocarum, a species quite distinct from lanceolatum, in the genus Pyramicocephalus.

Diphyllobothrium osmeri (von Linstow, 1878) Kuhlow, 1953

Host: Phoca vitulina richardi - harbour seal. Location: Intestine.

Locality: Alaska.

Recorded by: Neiland (1962).

Diphyllobothrium pacificum (Nybelin, 1931) Margolis, 1956

Syns.: Bothriocephalus sp. Stiles and Hassall, 1899.

Adenocephalus septentrionalis $\mathrm{Ny}$ belin, 1931.

Cordicephalus arctocephalinus (Johnston, 1937) Wardle, McLeod, and Stewart, 1947, in part. “Species No. 2" of Stunkard, 1948.
Diphyllobothrium glaciale (Cholodkovsky, 1915) Markowski, 1952.

Diphyllobothrium krotovi Delyamure, 1955.

Hosts: Callorhinus ursinus - northern fur seal; Eumetopias jubatus - Steller sea lion; Zalophus californianus - California sea lion.

Location: Intestine.

Localities: Alaska; British Columbia; California.

Recorded by: Stiles and Hassall (1899) ; Nybelin (1931) ; Wardle, McLeod, and Stewart (1947); Stunkard (1948); Markowski (1952); Margolis (1956); Keyes (1965); Dailey and Hill (1970).

Remarks: For a review of the history and synonymy of this species see Margolis (1954a, 1956) and Baer et al. (1967).

Diphyllobothrium schistochilus (Germanos, 1895) Meggitt, 1924

Host: Erignathus barbatus - bearded seal.

Location: Intestine.

Locality: Alaska.

Recorded by: Johnson et al. (1966).

Diplogonoporus sp.

Host: Callorhinus ursinus - northern fur seal. Location: Intestine.

Locality: Alaska.

Recorded by: Keyes (1965).

Diplogonoporus balaenopterae Lönnberg, 1892

Host: Megaptera novaeangliae - humpback whale; unidentified whale.

Location: Intestine.

Localities: Washington; California.

Recorded by: Rice (1963); Rausch (1964).

Diplogonoporus fasciatus (Krabbe, 1865) Lühe, 1899

Syn.: Diplogonoporus sp. Stunkard, 1948. Host: Eumetonias jubatus - Steller sea lion. Location: Intestine.

Locality: Alaska.

Recorded by: Stunkard (1948).

Remarks: Stunkard (1948) believed his $D i$ plogonoporus sp. was possibly conspecific with D. fasciatus (Krabbe, 1865), but different from the Diplogonoporus sp. from the 
Diplogonoporus fasciatus-Cont. northern fur seal. Markowski (1952) considered Stunkard's material as D. fasciatus.

Diplogonoporus tetrapterus (von Seibold, 1848) Ariola, 1896

Syn.: Diplogonoporus sp. Stunkard, 1948.

Hosts: Callorhinus ursinus - northern fur seal; Enhydra lutris - sea otter; Eumetopias jubatus - Steller sea lion.

Location: Intestine.

Localities: Alaska; British Columbia.

Recorded by: Stunkard (1948); Margolis (1956); Rausch (1964); Kenyon (1969).

Remarks: Diplogonoporus sp. of Stunkard (1948) was considered as D. tetrapterus by Markowski (1952), with D. variabilis as a synonym.

Phyllobothrium delphini (Bosc, 1802)

Hosts: Balaenoptera physalus - fin whale; Berardius bairdi - North Pacific giant bottlenose whale; Delphinus delphis - common dolphin; Lagenorhynchus obliquidens - Pacific white-sided dolphin; Physeter catodon sperm whale.

Location: Blubber.

Localities: British Columbia; California.

Recorded by: Margolis and Pike (1955); Rice (1963); Ridgway and Johnston (1965); Johnston and Ridgway (1969) .

Remarks: A review of the literature on this cestode, which has an involved history, can be found in Delyamure (1955), Dollfus (1964), and Williams (1968).

Pyramicocephalus phocarum (Fabricius, 1780) Monticelli, 1890

Hosts: Enhydra lutris - sea otter; Erignathus barbatus - bearded seal; Phoca sp.; Phocoena phocoena - harbour porpoise.

Location: Intestine.

Locality: Alaska.

Recorded by: Rausch (1953); Hilliard (1960); Kenyon (1962); Johnson et al. (1966); Rausch and Hilliard (1970).

Remarks: Adult worms have been found only in the intestines of sea otter and the bearded seal. Plerocercoids have been found free in the stomach of Phoca sp. and the harbour porpoise.
Tetrabothrius sp.

Hosts: Balaenoptera borealis - sei whale; Eschrichtius gibbosus - gray whale.

Location: Intestine.

Locality: California.

Recorded by: Rice (1963).

\section{Nematoda}

Anisakis sp.

Hosts: Balaenoptera borealis - sei whale; Balaenoptera physalus - fin whale; Berardius bairdi - North Pacific giant bottle-nose whale; Megaptera novaeangliae - humpback whale; Orcinus orca - killer whale; Physeter catodon - sperm whale; Ziphius cavirostris goose-beaked whale.

Location: Stomach.

Localities: Alaska; British Columbia; Washington; California.

Recorded by: Scheffer and Slipp (1948) ; Margolis and Pike (1955); Kenyon (1961); Rice (1963).

Anisakis physeteris Baylis, 1923

Host: Physeter catodon - sperm whale.

Locations: Stomach and intestine.

Localities: Alaska; British Columbia.

Recorded by: Scheffer (1939); Margolis and Pike (1955).

Anisakis similis (Baird, 1853) Baylis, 1920

Hosts: Eumetopias jubatus - Steller sea lion; Mirounga angustirostris - northern elephant seal; Zalophus californianus - California sea lion.

Location: Stomach.

Localities: California (San Diego Zoo); Baja California; Switzerland (Bäsel Zoo).

Recorded by: Schroeder and Wegeforth (1935); Caballero and Peregrina (1938); Kreis (1940); Herman (1942).

Remarks: Schroeder and Wegeforth (1935) reported stomach nematodes from the California sea lion, northern elephant seal, harbour seal, and "Galapagos fur seal" (Arctocephalus australis galapagoensis) from Baja California and the San Diego Zoo as Anisakis similis and Contracaecum osculatum, but 
with one exception they did not indicate in which pinniped $(\mathrm{s})$ each of the nematode species was found. Their Figure 2 bears the caption "Ulcer crater, California sea lion, male, adult, imbedded with Anisikis [sic] similis ad." Kreis' (1940) specimens of $A$. similis from the Bäsel Zoological Gardens were obtained from "Otaria jubata Desm." Although it is not certain, we are considering this host to be Eumetopias jubatus.

Anisakis simplex (Rudolphi, 1809) Baylis, 1920 Hosts: Balaenoptera borealis - sei whale; Berardius bairdi - North Pacific giant bottlenose whale; Orcinus orca - killer whale; Phocoenoides dalli - Dall porpoise; Physeter catodon - sperm whale.

Location: Stomach.

Locality: British Columbia.

Recorded by: Mueller (1927a, b); Cornwall (1928) ; Margolis and Pike (1955).

Remarks: The records from Phocoenoides dalli and Orcinus orca are reported here for the first time.

Anisakis typica (Diesing, 1860) Baylis, 1920

Syns.: Ascaris typica Diesing, 1860. Ascaris simplex of Leidy, 1886.

Host: Unidentified dolphin (?Delphinus sp.). Location: Stomach.

Locality: Unspecified region of the Pacific.

Recorded by: Leidy (1886).

Remarks: This record is included here with reservations because it is not known if the host was captured in waters off North America. Stiles and Hassall (1899) re-examined Leidy's specimens and identified them as Ascaris typica. Lyster (1940) and Margolis and Pike (1955) regarded Anisakis typica (Diesing, 1860) as a synonym of Anisakis simplex (Rudolphi, 1809), but recent studies (Kagei, Oshima, and Takemura, 1967; Kagei, 1969) support the view that they are distinct species.

\section{Contracaecum sp.}

Host: Lagenorhynchus obliquidens - Pacific white-sided dolphin.

Location: Brain.

Locality: California.

Recorded by: Martin et al. (1970).
Contracaecum sp. (larva)

Host: Pusa hispida - ringed seal.

Location: Stomach.

Locality: Alaska.

Recorded by: Johnson et al. (1966) .

Contracaecum osculatum (Rudolphi, 1802) Baylis, 1920

Syn.: Ascaris osculata Rudolphi, 1802.

Hosts: Callorhinus ursinus - northern fur seal; Eumetopias jubatus - Steller sea lion; Mirounga angustirostris - northern elephant seal; Phoca vitulina richardi - harbour seal; Zalophus californianus - California sea lion.

Location: Stomach and intestine, abnormally in brain.

Localities: Alaska; British Columbia; California; Baja California; Baltimore Zoo.

Recorded by: Stiles and Hassall (1899); Schroeder and Wegeforth (1935) ; Caballero and Peregrina (1938); Herman (1942); Fisher (1952); Margolis (1956); FloresBarroeta et al. (1961); Keyes (1965) ; Johnson et al. (1966); Johnston and Ridgway (1969) ; Dailey and Hill (1970) ; Fleischman and Squire (1970).

Remarks: See Anisakis similis for comments on Schroeder and Wegeforth's (1935) records.

Crassicauda sp.

Hosts: Balaenoptera borealis - sei whale; Balaenoptera physalus - fin whale; Megaptera novaeangliae - humpback whale.

Location: Kidneys.

Locality: California.

Recorded by: Rice (1963).

Crassicauda pacifica Margolis and Pike, 1955 Host: Balaenoptera physalus - fin whale.

Location: Kidneys.

Locality: British Columbia.

Recorded by: Margolis and Pike (1955).

Dipetalonema odendhali Perry, 1967

Host: Zalophus californianus - California sea lion.

Locations: Muscle fascia, thoracic and abdominal cavities.

Locality: California (wild and captive sea lions).

Recorded by: Perry (1967); Dailey and Hill (1970). 
Dipetalonema odendhali_Cont.

Remarks: Perry (1967) noted that Anderson's (1959) specimens from the testicular sheat̂h, subcutaneous tissue, and upper colon of northern fur seals from Alaska, which the latter author doubtfully referred to Dipetalonema spirocauda, may belong to $D$. odendhali.

Dipetalonema spirocauda (Leidy, 1858) Anderson, 1959

Hosts: (?) Callorhinus ursinus - northern fur seal; Phoca vitulina richardi - harbour seal.

Location: Heart.

Localities: (?) Alaska; California (captive harbour seals).

Recorded by: Anderson (1959); Taylor et al. (1961); Keyes (1965).

Remarks: Like Anderson's (1959) specimens from the northern fur seal from Alaska (see Dipetalonema odendhali), the specimens reported by Keyes (1965) from subcutaneous tissues of the same host species from the same locality may be $D$. odendhali. D. spirocauda and $D$. odendhali apparently differ in their sites of infection, the former being found in the heart and main arteries and the latter mainly in connective tissues (see Perry, 1967). For synonymy and a review of the taxonomy of D. spirocauda, see Anderson (1959).

Dirofilaria immitis (Leidy, 1856) Ralliet and Henry, 1911

Syns.: Dirofilaria spirocauda (Leidy, 1858) sub judice Faust, 1937.

Dirofilaria fausti Skrjabin and Shikhobalova, 1948.

Host: Zalophus californianus - California sea lion.

Location: Heart.

Locality: Zoological Garden, New Orleans, La. (animal captured at Sea Cliffs, Calif.) . Recorded by: Faust (1937).

Remarks: Faust (1937) did not definitely decide on the specific identity of his specimens. $\mathrm{He}$ recognized that they were morphologically indistinguishable from the type material of Dirofilaria immitis; however, he associated them provisionally with Filaria spirocauda Leidy, 1958 (the types of which were not available for restudy) under the name
Dirofilaria spirocauda (sub judice). Skrjabin and Shikhobalova (1948) named a new species, D. fausti, for Faust's material. Faust's specimens are now accepted as $D$. immitis, and Filaria spirocauda is regarded as a distinct species, Dipetalonema spirocauda (see Anderson, 1959). Perry (1967) expressed doubt that $D$. immitis occurs enzootically in California sea lions and implied that the sea lion examined by Faust could have acquired its infection in New Orleans, where $D$. immitis is enzootic.

Dujardinia sp.

Host: Zalophus californianus - California sea lion.

Location: Stomach.

Locality: California (San Diego Zoo).

Recorded by: Herman (1942).

Halocercus invaginatus (Queckitt, 1841)

Dougherty, 1943

Host: Phocoena phocoena - harbour porpoise. Location: Lungs.

Localities: Washington; California.

Recorded by: Dougherty (1943a, 1944); Scheffer and Slipp (1948).

Halocercus kirbyi Dougherty, 1944

Syn.: Halocercus sp. of Benson and Groody, 1942 and of Dougherty, 1943.

Host: Phocoenoides dalli - Dall porpoise.

Location: Lungs.

Locality: California.

Recorded by: Benson and Groody (1942); Dougherty (1943a, 1944).

Parafilaroides sp. Dougherty and Herman, 1947 Host: Eumetopias jubatus - Steller sea lion. Location: Lungs.

Localities: British Columbia; California (wild and captive animals).

Recorded by: Dougherty and Herman (1947); Margolis (1956); Dailey and Hill (1970).

Parafilaroides decorus Dougherty and Herman, 1947

Syns.: Filaroides sp. of Dougherty, 1943. Parafilaroides sp. of Dougherty, 1946.

Host: Zalophus californianus - California sea lion. 
Location: Lungs.

Locality: California (wild and captive animals); Baltimore Zoo.

Recorded by: Dougherty (1943b, 1946); Dougherty and Herman (1947); Johnston and Ridgway (1969); Dailey (1970); Dailey and Hill (1970); Fleischman and Squire (1970).

Parafilaroides nanus Dougherty and Herman, 1947

Syns.: Filaroides sp. of Dougherty, 1943.

Parafilaroides sp. of Dougherty,

1946.

Host: Eumetopias jubatus - Steller sea lion.

Location: Lungs.

Locality: California (San Diego Zoo).

Recorded by: Dougherty (1943b, 1946);

Dougherty and Herman (1947).

Parafilaroides prolificus Dougherty and Herman, 1947

Syns.: Filaroides sp. of Dougherty, 1943.

Parafilaroides sp. of Dougherty, 1946.

Host: Eumetopias jubatus - Steller sea lion.

Location: Lungs.

Locality: California (San Diego Zoo).

Recorded by: Dougherty (1943b, 1946);

Dougherty and Herman (1947).

Pharurus convolutus (Kühn, 1829) Dougherty, 1943

Host: Phocoena phocoena - harbour porpoise.

Location: Lungs.

Localities: Washington; California.

Recorded by: Dougherty (1943a); Scheffer and Slipp (1948).

Remarks: Soviet authors (see Skrjabin et al., 1952; Delyamure, 1955) do not recognize Pharurus Leuckart, 1848 as a valid genus. They use the designation Torynurus convolutus (Kühn, 1829) Baylis and Daubney, 1925 for this species. Dougherty (1943a) considered Torynurus Baylis and Daubney, 1925 as a synonym of Pharurus.

Pharurus oserkaiae (Skrjabin, 1942) Dougherty, 1949

Host: Delphinapterus leucas - white whale.

Location: Head sinuses.

Locality: Alaska.
Recorded by: Babero and Thomas (1960).

Remarks: Dougherty (1949) considered Otophocaenurus Skrjabin, 1942 to be a synonym of Pharurus Leukart, 1848, and transferred O. oserskoi Skrjabin, 1942 to the latter genus. This view was upheld by Babero and Thomas (1960) but not by Soviet authors (see Skrjabin et al., 1952; Delyamure, 1955). The specific name was modified by Dougherty (1949) from oserskoi to oserskaiaae and subsequently emended (Dougherty, 1951) to oserskaiae. Babero and Thomas (1960) spelled the specific name oserkaiae.

Placentonema sp.

Host: Phocoenoides dalli - Dall porpoise.

Location: Mammary glands.

Locality: California.

Recorded by: Ridgway (1966); Johnston and Ridgway (1969).

Placentonema gigantissima Gubanov, 1951

Host: Physeter catodon - sperm whale.

Location: Placenta.

Locality: California.

Recorded by: Rice (1963).

Porrocaecum sp.

Host: Zalophus californianus - California sea lion.

Location: Stomach.

Locality: California (San Diego Zoo).

Recorded by: Herman (1942).

Remarks: This species is undoubtedly a Terranova, likely $T$. decipiens.

Stenurus minor (Kühn, 1829) Baylis and Daubney, 1925

Syns.: Stenurus phocoenae Dougherty, 1943. Stenurus vagans (Eschricht, 1841) Dougherty, 1943.

Hosts: Phocoena phocoena - harbour porpoise; Phocoenoides dalli - Dall porpoise.

Locations: Lungs and head sinuses.

Locality: California.

Recorded by: Dougherty (1943a, c); Johnston and Ridgway (1969).

Remarks: Dougherty $(1943 \mathrm{a}, \mathrm{c})$ argued that the name minor was not available for this nematode and proposed for it first the new name phocoenae and later vagans. His views seem not to have been generally accepted. 
Terranova decipiens (Krabbe, 1878) Mozgovoy, 1951

Syns.: Ascaris decipiens Krabbe, 1878.

Porrocaecum decipiens (Krabbe, 1878) Baylis, 1920.

Phocanema decipiens (Krabbe, 1878) Myers, 1959.

Hosts: Callorhinus ursinus - northern fur seal; Enhydra lutris - sea otter; Erignathus barbatus - bearded seal; Eumetopias jubatus - Steller sea lion; Phoca vitulina richardi harbour seal; Pusa hispida - ringed seal.

Location: Stomach.

Localities: Alaska; British Columbia; Washington.

Recorded by: Stiles and Hassall (1899); Scheffer and Slipp (1944) ; Scheffer (1945); Fisher (1952); Rausch (1953); Schiller (1954); Margolis (1956); Neiland (1961); Kenyon (1962, 1969); Keyes (1965); Johnson et al. (1966).

Remarks: The nomenclatural combination Terranova decipiens apparently was first published by either Mozgovoy (1951) or Skrjabin et al. (1951). According to information received from colleagues in the USSR it is not known which of these two publications was issued first. The corrected proofs of Mozgovoy (1951) and Skrjabin et al. (1951) were returned to the publisher on July 20, 1951, and June 4, 1951 (the "podpisano $\mathrm{k}$ pechati" dates shown on these publications), respectively, but it does not follow that the first to be returned was necessarily the first to be published. In view of this uncertainty it would seem just to consider Mozgovoy as the author of the combination $T$. decipiens because apparently he used this name in a thesis written in 1949 and, as a co-author of Skrjabin et al. (1951), he was responsible for the section on Ascaridata in that book. Authors who have been erroneously regarded as the originators of the combination T. decipiens are Baylis (1916), Johnston and Mawson (1945), and Mozgovoy (1953) (see Mozgovoy, 1951, 1953; Skrjabin et al., 1951; Margolis, 1956; Myers, 1959).
Trichinella spiralis (Owen, 1835) Railliet, 1895 (larva)

Host: Odobenus rosmarus - walrus; Phoca sp.

Location: Muscle.

Locality: Alaska.

Recorded by: Rausch et al. (1956); Fay (1960).

Remarks: Rausch et al. (1956) also reported Trichinella spiralis larvae from Erignathus barbatus and Delphinapterus leucas in Arctic Alaska.

Uncinaria sp.

Host: Zalophus californianus - California sea lion.

Location: Intestine.

Locality: California.

Recorded by: Dailey and Hill (1970).

Remarks: Dailey and Hill (1970) considered their specimens to be identical with those tentatively identified by Baylis (1933) from a sea lion from the San Francisco Bay area as Uncinaria hamiltoni (see below).

Uncinaria hamiltoni Baylis, 1933

Host: (?) Eumetopias jubatus - Steller sea lion.

Location: Intestine.

Locality: California.

Recorded by: Baylis (1933, 1947).

Remarks: Baylis doubtfully assigned material obtained "from a sea lion at Palo Alto, San Francisco Bay, California” to Uncinaria hamiltoni although the measurements did not agree with the material collected from Otaria byronia. Baylis assumed the sea lion was Eumetopias jubatus inasmuch as it is the "commoner of the two species of sea lions occurring in the region of San Francisco Bay." Accepting the validity of Dochmoides Cameron, 1924 as a replacement for Uncinaria Frölich, 1789, Wolfgang (1956) transferred U. hamiltoni to Dochmoides.

Uncinaria lucasi Stiles, 1901

Syn.: Uncinaria sp. of Stiles and Hassall, 1899.

Hosts: Callorhinus ursinus - northern fur seal; Eumetopias jubatus - Steller sea lion. Location: Intestine. 
Locality: Alaska.

Recorded by: Stiles and Hassall (1899); Stiles (1901); Baylis (1947); Olsen (1958); Olsen and Lyons (1962, 1965); Keyes (1965).

Unidentified microfilariae

Hosts: Zalophus californianus - California sea lion; Eumetopias jubatus - Steller sea lion.

Location: Blood.

Locality: California (animals in captivity, originally caught off California coast).

Recorded by: Taylor et al. (1961); Perry (1967).

\section{Acanthocephala}

Bolbosoma sp.

Hosts: Balaenoptera borealis - sei whale; Balaenoptera musculus - blue whale; Megaptera novaeangliae - humpback whale.

Location: Intestine.

Locality: California.

Recorded by: Rice (1963).

Bolbosoma balaenae (Gmelin, 1790) Meyer, 1932

Host: Unidentified whale.

Location: Intestine.

Locality: Washington.

Recorded by: Van Cleave (1953b) .

Bolbosoma turbinella (Diesing, 1851) Porta, 1908

Host: Balaenoptera borealis - sei whale.

Location: Intestine.

Locality: British Columbia.

Recorded by: Margolis and Pike (1955).

Corynosoma sp.

Host: Pusa hispida - ringed seal.

Location: Intestine.

Locality: Alaska.

Recorded by: Johnson et al. (1966) .

Corynosoma alaskensis Golvan, 1959

Host: Phocoena phocoena - harbour porpoise.

Location: Intestine.

Locality: Alaska.

Recorded by: Golvan (1959).
Corynosoma enhydri Morosov, 1940

Syns.: Corynosoma macrosomum Neiland, 1962.

Corynosoma sp. of Van Cleave, 1953.

Host: Enhydra lutris - sea otter.

Location: Intestine.

Locality: Alaska.

Recorded by: Van Cleave (1953b); Neiland (1962); Kenyon (1969).

Remarks: In a mimeographed report by Jellison and Neiland (1965), Corynosoma macrosomum is recognized as a synonym of $C$. enhydri.

Corynosoma falcatum Van Cleave, 1953

Host: Phoca vitulina richardi - harbour seal.

Location: Intestine.

Locality: Alaska.

Recorded by: Van Cleave (1953a, b).

Remarks: Van Cleave gave the host as Halichoerus grypus, the gray seal. Kruidenier (1954) pointed out that this species of seal does not occur in the Pacific and that the host was almost certainly Phoca vitulina richardi.

Corynosoma obtuscens Lincicome, 1943

Host: Zalophus californianus - California sea lion.

Location: Intestine.

Locality: California (wild and captive animals).

Recorded by: Lincicome (1943); Van Cleave (1953a, b) ; Dailey and Hill (1970).

Corynosoma semerme (Forssell, 1904) Lühe, 1911

Hosts: Callorhinus ursinus - northern fur seal; Delphinapterus leucas - white whale; Phoca vitulina richardi - harbour seal; unidentified seals.

Location: Intestine.

Locality: Alaska.

Recorded by: Van Cleave (1953b) ; Neiland (1962).

Remarks: Fisher's (1952) report of this species from the harbour seal in British Columbia proved to be erroneous; his specimens were redetermined as Corynosoma strumosum (see Margolis, 1956). 
Corynosoma similis Neiland, 1962

Hosts: Callorhinus ursinus - northern fur seal; Delphinapterus leucas - white whale.

Location: Intestine.

Locality: Alaska.

Recorded by: Neiland (1962).

Corynosoma strumosum (Rudolphi, 1802)

Lühe, 1904

Syn.: Corynosoma osmeri Fujita, 1921.

Hosts: Callorhinus ursinus - northern fur seal; Delphinapterus leucas - white whale; Enhydra lutris - sea otter; Eumetopias jubatus - Steller sea lion; Phoca vitulina richardi - harbour seal; Phoca sp.; Zalophus californianus - California sea lion; unidentified seals.

Location: Intestine.

Localities: Alaska; British Columbia; Washington; California.

Recorded by: Ball (1930); Lincicome (1943); Scheffer and Slipp (1944); Van Cleave (1953a, b); Rausch (1953); Margolis (1956); Neiland (1961, 1962); Keyes (1965); Kenyon (1969); Dailey and Hill (1970).

Remarks: Van Cleave (1953a, b) considered Corynosoma osmeri Fujita, 1921, recorded by Lincicome (1943) from the California sea lion, as a synonym of $C$. strumosum. Halichoerus grypus was erroneously included by Van Cleave (1953b) as a host of C. strumosum in Alaska; according to Kruidenier (1954) this host was almost certainly Phoca vitulina richardi.

Corynosoma validum Van Cleave, 1953

Hosts: Erignathus barbatus - bearded seal; Odobenus rosmarus - walrus; Phoca sp.; unidentified seal.

Location: Intestine.

Locality: Alaska.

Recorded by: Van Cleave (1953a, b); Kenyon (1962).

Corynosoma villosum Van Cleave, 1953

Syn.: Corynosoma sp. of Rausch and Locker, 1951 and Rausch, 1953.

Hosts: Callorhinus ursinus - northern fur seal; Enhydra lutris - sea otter; Eumetopias jubatus - Steller sea lion; unidentified seal.

Location: Intestine.
Localities: Alaska; British Columbia.

Recorded by: Rausch and Locker (1951); Rausch (1953); Van Cleave (1953a, b); Schiller (1954); Margolis (1956); Golvan (1959).

Corynosoma wegeneri Heinze, 1934

Syn.: Corynosoma hadweni Van Cleave, 1953.

Hosts: Delphinapterus leucas - white whale; Phoca vitulina richardi - harbour seal; Phoca sp.; Pusa hispida - ringed seal; unidentified seals.

Location: Intestine.

Locality: Alaska.

Recorded by: Van Cleave (1953a, b); Neiland (1962).

Remarks: Margolis (1955b) considered Corynosoma hadweni to be a synonym of $C$. wegeneri. Halichoerus grypus was erroneously included by Van Cleave (1953a, b) as a host of $C$. hadweni in Alaska; according to Kruidenier (1954) this host was almost certainly Phoca vitulina richardi.

\section{Copepoda}

Pennella balaenopterae Koren and Danielssen, 1877

Hosts: Balaenoptera borealis - sei whale; Balaenoptera physalus - fin whale.

Location: Head embedded in blubber, trunk external.

Localities: British Columbia; California.

Recorded by: Cornwall (1927, 1928, 1955); Rice (1963).

\section{Amphipoda}

Cyamus sp.

Host: Berardius bairdi - North Pacific giant bottle-nose whale.

Location: Skin.

Localities: British Columbia; California.

Recorded by: Rice (1963) ; Leung (1965) .

Cyamus balaenopterae Barnard, 1932

Hosts: Balaenoptera acutorostrata - minke whale; Balaenoptera musculus - blue whale; Balaenoptera physalus - fin whale. 
Location: Skin.

Localities: Alaska; British Columbia; California.

Recorded by: Margolis (1959); Leung (1965).

Remarks: The record from the blue whale (California) was previously unpublished and is based on a collection obtained for identification from D. W. Rice, National Marine Fisheries Service, Seattle.

Cyamus boopis Lütken, 1870

Syns.: Cyamus suffusus Dall, 1872.

Paracyamus boopis (Lütken, 1870) Sars, 1895.

Host: Megaptera novaeangliae - humpback whale.

Location: Skin.

Localities: Alaska; British Columbia; California.

Recorded by: Dall (1872a, b); Scammon (1874) ; Cornwall (1928) ; Scheffer (1939); Margolis (1954b, 1955a); Rice (1963); Leung (1965).

Remarks: For review of synonymy and taxonomy see Margolis (1954a, b; 1955a).

Cyamus catodontis Margolis, 1954

Host: Physeter catodon - sperm whale.

Location: Skin.

Locality: British Columbia.

Recorded by: Margolis (1954b, 1955a); Leung (1965).

Cyamus ceti (Linnaeus, 1758) Lamarck, 1801 Syn.: Cyamus mysticeti Lütken, 1870; Dall, 1872.

Hosts: Balaena mysticetus - bowhead whale; Eschrichtius gibbosus - gray whale.

Location: Skin.

Localities: Alaska; California.

Recorded by: Dall (1872b); Scammon (1874) ; Rice (1963); Leung (1965).

Cyamus erraticus R. de Vauzème, 1834

Host: Balaena glacialis - black right whale. Location: Skin.

Localities: Alaska; British Columbia.

Recorded by: Margolis (1955a).

Remarks: The Alaskan record is based on specimens received for identification from $D$. W. Rice, National Marine Fisheries Service,
Seattle, and has not been published previously.

Cyamus gracilis $\mathrm{R}$. de Vauzème, 1834

Syn.: Cyamus gracilis Dall, 1874.

Host: Balaena glacialis - black right whale. Location: Skin.

Locality: Alaska.

Recorded by: Dall (1874); Leung (1965).

Remarks: Lütken (1887) re-examined Dall's specimens and found them to be identical with Cyamus gracilis R. de Vauzème, 1834.

Cyamus kessleri Brandt, 1872

Host: Eschrichtius gibbosus - gray whale.

Location: Skin.

Locality: California.

Recorded by: Leung (1965).

Remarks: This whale-louse has been reported from Arctic Alaska (Hurley and Mohr, 1957; Leung, 1965).

Cyamus ovalis $\mathrm{R}$. de Vauzème, 1834

Syn.: Cyamus tentator Dall, 1874.

Host: Balaena glacialis - black right whale.

Location: Skin.

Locality: Alaska.

Recorded by: Dall (1874).

Remarks: Lütken (1887) re-examined some of Dall's specimens of $C$. tentator and found them to be identical with $C$. ovalis.

Cyamus scammoni Dall, 1872

Host: Eschrichtius gibbosus - gray whale.

Location: Skin.

Localities: Alaska; British Columbia; California.

Recorded by: Dall (1872a); Scammon (1874); Lütken (1887); Margolis (1954b, 1955a); Rice (1963); Leung (1965).

Remarks: The Alaskan record was previously unpublished and is based on material collected at St. Lawrence Island in the Bering Sea by Dr. F. H. Fay, Arctic Health Research Laboratory, College, Alaska. Hurley and Mohr (1957) and Leung (1965) reported this species from the Arctic coast of Alaska.

Neocyamus physeteris (Pouchet, 1888) Margolis, 1955

Host: Physeter catodon - sperm whale.

Location: Skin. 
Neocyamus physeteris-Cont.

Locality: British Columbia.

Recorded by: Margolis (1959); Leung (1965).

Platycyamus sp.

Host: Berardius bairdi - North Pacific giant bottle-nose whale.

Location: Skin.

Locality: British Columbia.

Recorded by: Leung (1965).

Syncyamus sp.

Host: Tursiops truncatus - bottle-nosed dolphin.

Location: Skin.

Locality: Mexico.

Recorded by: Leung (1967).

Syncyamus sp.

Host: Stenella longirostris - long-beaked dolphin.

Location: Skin.

Locality: Mexico.

Recorded by: Leung (1970).

\section{Anoplura}

Antarctophthirus callorhini (Osborn, 1899) McAtee, 1923

Syns.: Haematopinus callorhini Osborn, 1899.

Antarctophthirus monachus Kellogg and Ferris, 1915.

Host: Callorhinus ursinus - northern fur seal. Location: Skin.

Locality: Alaska.

Recorded by: Osborn (1899) ; Kellogg and

Ferris (1915); McAtee (1923); Ferris (1934, 1951); Jellison (1952); Keyes (1965) .

Antarctophthirus microchir (Trouessart and Neumann, 1888) Enderlein, 1906

Hosts: Eumetopias jubatus - Steller sea lion; Phoca vitulina richardi - harbour seal; $Z a$ lophus californianus - California sea lion.

Location: Skin.

Localities: Alaska; British Columbia; California (wild and captive animals).

Recorded by: Ferris (1916, 1934, 1951); Doetschman (1944b); Jellison (1952);
Margolis (1956); Thorsteinson and Lensink (1962); Dailey and Hill (1970).

Remarks: The only report of this louse from the harbour seal was from captive animals in the San Diego Zoo where Doetschman (1944b) found it on all three hosts listed above.

Antarctophthirus trichechi (Bohemann, 1865) Enderlein, 1909

Host: Odobenus rosmarus - walrus.

Location: Skin.

Locality: Alaska.

Remarks: This record is based on information received from the late Prof. G. J. Spencer, University of British Columbia, who identified a collection of lice from walrus taken at St. Lawrence Island in the Bering Sea (personal communication to L. Margolis, February 25, 1955). Weber (1950) previously reported this species from the walrus in Arctic Alaska (Point Barrow).

Echinophthirius horridus (Olfers, 1816) Fahrenholz, 1919

Hosts: Phoca vitulina richardi - harbour seal; Pusa hispida - ringed seal.

Location: Skin.

Localities: Alaska; British Columbia; California (wild and captive animals).

Recorded by: Ferris $(1934,1951)$; Margolis (1956); Brown et al. (1960); Taylor et al. (1961).

Proechinophthirus fluctus (Ferris, 1916) Ewing, 1923

Syn.: Echinophthirius fluctus Ferris, 1916.

Hosts: Callorhinus ursinus - northern fur seal; Eumetopias jubatus - Steller sea lion.

Location: Skin.

Localities: Alaska; California (Stanford Museum specimen).

Recorded by: Ferris (1916, 1934, 1951); Ewing (1923); McAtee (1923); Keyes (1965).

\section{Acarina}

Halarachne sp.

Hosts: Eumetopias jubatus - Steller sea lion; Phoca vitulina richardi - harbour seal. 
Location: Naso-pharynx.

Localities: British Columbia; California.

Recorded by: Ferris (1942); Fisher (1952) ; Margolis (1956).

Halarachne halichoeri Allman, 1847

Syn.: Halarachne otariae of Ferris, 1925, in part.

Host: Phoca vitulina richardi - harbour seal. Location: Naso-pharynx.

Localities: Washington; California.

Recorded by: Ferris (1925, 1942); Scheffer and Slipp (1944).

Remarks: Ferris (1925) identified specimens from Pacific Grove, Calif., as Halarachne otariae Steding, 1923. In 1942 he redetermined these specimens as $H$. halichoeri. Newell (1947) doubted the existence of this species on the Pacific coast of North America and referred the above records of it to H. miroungae.

Halarachne miroungae Ferris, 1925

Hosts: Enhydra lutris - sea otter; Mirounga angustirostris - northern elephant seal; Phoca vitulina richardi - harbour seal.

Location: Naso-pharynx.

Localities: Alaska; California (San Diego Zoo); Baja California.

Recorded by: Ferris (1925, 1942); Doetschman (1941); Newell (1947); Kenyon et al. (1965); Kenyon (1969).

Orthohalarachne attenuata (Banks, 1910) Newell, 1947

Syn.: Halarachne attenuata Banks, 1910.

Hosts: Callorhinus ursinus - northern fur seal; Eumetopias jubatus - Steller sea lion; Zalophus californianus - California sea lion.

Location: Naso-pharynx.

Localities: Alaska; Oregon; California.

Recorded by: Banks (1910); Oudemans (1926); Newell (1947); Keyes (1965); Dailey and Hill (1970).

Orthohalarachne diminuata (Doetschman, 1944) Newell, 1947

Syn.: Halarachne diminuata Doetschman, 1944.

Hosts: Callorhinus ursinus - northern fur seal; Eumetopias jubatus - Steller sea lion; Zalophus californianus - California sea lion.
Location: Bronchioles and trachea.

Localities: Alaska; British Columbia; California.

Recorded by: Doetschman (1944a); Newell (1947) ; Margolis (1956); Thorsteinson and Lensink (1962); Keyes (1965); Dailey (1970); Dailey and Hill (1970).

Remarks: Thorsteinson and Lensink (1962) referred to their specimens from Eumetopias jubatus as "nose mites." It seems likely, therefore, that they had either Orthohalarachne attenuata or O. zalophi, which occur in the nasal passages, rather than O. diminuata, which occurs deeper in the respiratory system.

Orthohalarachne zalophi (Oudemans, 1916) Newell, 1947

Syns.: Halarachne zalophi Oudemans, 1916.

Halarachne otariae Steding, 1923.

Hosts: Eumetopias jubatus - Steller sea lion; Zalophus californianus - California sea lion.

Location: Naso-pharynx.

Localities: California (wild and captive animals); Germany (Göttingen Zoo).

Recorded by: Oudemans (1916, 1926); Steding (1923); Doetschman (1941); Ferris (1942); Newell (1947).

Remarks: Oudemans (1916) and Steding (1923) described Halarachne zalophi and $H$. otariae, respectively, from the same California sea lion in Göttingen. Ferris (1942) and Newell (1947) considered $H$. otariae identical with $H$. zalophi, the latter author transferring the species to Orthohalarachne.

\section{HOST-PARASITE LIST}

\section{Cetacea}

Balaena glacialis - black right whale.

Amphipoda: Cyamuserraticus, $C$. gracilis, $C$. ovalis.

Balaena mysticetus - northern bowhead whale. Amphipoda: Cyamus ceti.

Balaenoptera acutorostrata - minke whale. Amphipoda: Cyamus balaenopterae. 
Balaenoptera borealis - sei whale.

Trematoda: Lecithodesmus sp., L. spinosus, Ogmogaster plicatus.

Cestoda: Diphyllobothrium spp., Tetrabothrius sp.

Nematoda: Anisakis sp., A. simplex, Crassicauda sp.

Acanthocephala: Bolbosomasp., B.turbinella.

Copepoda: Pennella balaenopterae.

Balaenoptera musculus - blue whale.

Acanthocephala: Bolbosoma sp.

Amphipoda: Cyamus balaenopterae.

Balaenoptera physalus - fin whale.

Trematoda: Lecithodesmus goliath, Ogmogaster antarcticus, O. plicatus, O. trilineatus.

Cestoda: Phyllobothrium delphini.

Nematoda: Anisakis sp., Crassicauda sp., C. pacifica.

Copepoda: Pennella balaenopterae.

Amphipoda: Cyamus balaenopterae.

Berardius bairdi - North Pacific giant bottlenose whale.

Cestoda: Phyllobothrium delphini.

Nematoda: Anisakis sp., A. simplex.

Amphipoda: Cyamus sp., Platycyamus sp.

Delphinapterus leucas - white whale.

Trematoda: Hadwenius seymouri.

Nematoda: Pharurus oserskaiae.

Acanthocephala: Corynosoma semerme, $C$. similis, C. strumosum, C. wegeneri.

Delphinus delphis - common dolphin.

Trematoda: Nasitrema delphini.

Cestoda: Phyllobothrium delphini.

Eschrichtius gibbosus - gray whale.

Trematoda: Ogmogaster antarcticus, O. pentalineatus.

Cestoda: Tetrabothrius sp.

Amphipoda: Cyamus ceti, C. kessleri, C. scammoni.

Globicephala macrorhyncha - short-finned pilot whale.

Trematoda: Nasitrema globicephalae, N. lanceolata.
Lagenorhynchus obliquidens - Pacific whitesided dolphin.

Trematoda: Nasitrema globicephalae.

Cestoda: Phyllobothrium delphini.

Nematoda: Contracaecum sp.

Lissodelphis borealis - northern right-whale dolphin.

Trematoda: Nasitrema globicephalae.

Megaptera novaeangliae - humpback whale.

Trematoda: Lecithodesmus sp.

Cestoda: Diplogonoporus balaenopterae.

Nematoda: Anisakis sp., Crassicauda sp.

Acanthocephala: Bolbosoma sp.

Amphipoda: Cyamus boopis.

Orcinus orca - killer whale.

Nematoda: Anisakis sp., A. simplex.

Phocoena phocoena - harbour porpoise.

Trematoda: Campula oblonga, Hadwenius nipponicus.

Cestoda: Pyramicocephalus phocarum plerocercoids.

Nematoda: Halocercus invaginatus, Pharurus convolutus, Stenurus minor.

Acanthocephala: Corynosoma alaskensis.

Phocoenoides dalli - Dall porpoise.

Nematoda: Anisakis simplex, Halocercus kirbyi, Placentonema sp., Stenurus minor.

Physeter catodon - sperm whale.

Cestoda: Phyllobothrium delphini.

Nematoda: Anisakis sp., A. physeteris, A. simplex, Placentonema gigantissima.

Amphipoda: Cyamus catodontis, Neocyamus physeteris.

Pseudorca crassidens - false killer whale.

Trematoda: Nasitrema attenuata, N. globicephalae.

Stenella dubia - spotted dolphin.

Trematoda: Nasitrema stenosoma.

Stenella longirostris - long-beaked dolphin.

Amphipoda: Syncyamus sp. 
Tursiops truncatus - bottle-nose dolphin.

Trematoda: Braunina cordiformis.

Amphipoda: Syncyamus sp.

Ziphius cavirostris - goose-beaked whale.

Nematoda: Anisakis sp.

Unidentified dolphin.

Nematoda: Anisakis typica.

Unidentified whales.

Cestoda: Diplogonoporus balaenopterae.

Acanthocephala: Bolbosoma balanae.

\section{Pinnipedia}

Callorhinus ursinus - northern fur seal.

Trematoda: Cryptocotyle jejuna, Phocitrema fusiforme, Pricetrema zalophi.

Cestoda: Diphyllobothrium pacificum, Diplogonoporus sp., D. tetrapterus.

Nematoda: Contracaecum osculatum, Dipetalonema ( ?) spirocauda, Terranova decipiens, Uncinaria lucasi.

Acanthocephala: Corynosoma semerme, C. similis, C. strumosum, C. villosum.

Anoplura: Antarctophthirus callorhini, Proechinophthirus fluctus.

Acarina: Orthohalarachne attenuata, O. diminuata.

Erignathus barbatus - bearded seal.

Trematoda: Orthosplanchnus arcticus, O. fraterculus.

Cestoda: Diphyllobothrium cordatum, D. lanceolatum, D. schistochilus, Pyramicocephalus phocarum.

Nematoda: Terranova decipiens.

Acanthocephala: Corynosoma validum.

Eumetopias jubatus - Steller sea lion.

Trematoda: Pricetrema zalophi.

Cestoda: Abothrium gadi, Diphyllobothrium pacificum, Diplogonoporus fasciatus, D. tetrapterus.

Nematoda: Anisakis similis, Contracaecum osculatum, Parafilaroides sp., $P$. nanus, $P$. prolificus, Terranova decipiens, Uncinaria hamiltoni, $U$. lucasi, microfilariae.

Acanthocephala: Corynosoma strumosum, $C$. villosum.
Anoplura: Antarctophthirus microchir, Proechinophthirus fluctus.

Acarina: Halarachne sp., Orthohalarachne attenuata, O. diminuata, O. zalophi.

Mirounga angustirostris - northern elephant seal.

Nematoda: Anisakis similis, Contracaecum osculatum.

Acarina: Halarachne miroungae.

Odobenus rosmarus - walrus.

Nematoda: Trichinella spiralis (larva).

Acanthocephala: Corynosoma validum.

Anoplura: Antarctophthirus trichechi.

Phoca vitulina richardi - harbour seal.

Trematoda: Phocitrema fusiforme.

Cestoda: Diphyllobothrium alascense, D. lanceolatum, D. osmeri.

Nematoda: Contracaecum osculatum, Dipetalonema spirocauda, Terranova decipiens.

Acanthocephala: Corynosoma falcatum, $C$. semerme, $C$. strumosum, $C$. wegeneri.

Anoplura: Antarctophthirus microchir, Echinophthirius horridus.

Acarina: Halarachne sp., H. halichoeri(?), H. miroungae.

Pusa hispida - ringed seal.

Nematoda: Contracaecum sp., Terranova decipiens.

Acanthocephala: Corynosoma sp., C. wegeneri.

Anoplura: Echinophthirius horridus.

Zalophus californianus - California sea lion.

Trematoda: Pricetrema zalophi, Stictodora ubelakeri, Stephanoprora denticulata, Zalophotrema hepaticum.

Cestoda: Diphyllobothrium pacificum.

Nematoda: Anisakis similis, Contracaecum osculatum, Dipetalonema odendhali, Dirofilaria immitis, Dujardinia sp., Parafilaroides decorus, Porrocaecum sp., Uncinaria sp., microfilariae.

Acanthocephala: Corynosoma obtuscens, $C$. strumosum.

Anoplura: Antarctophthirus microchir.

Acarina: Orthohalarachne attenuata, O. diminuata, O. zalophi. 
Unidentified seals.

Cestoda: Pyramicocephalus phocarum plerocercoids.

Acanthocephala: Corynosoma semerme, $C$. strumosum, C. validum, C. villosum, C. wegeneri.

Nematoda: Trichinella spiralis (larva).

\section{Carnivora}

Enhydra lutris - sea otter.

Trematoda: Orthosplanchnus fraterculus, Microphallus pirum, Phocitrema fusiforme, Pricetrema zalophi.

Cestoda: Diplogonoporus tetrapterus, Pyramicocephalus phocarum.

Nematoda: Terranova decipiens.

Acanthocephala: Corynosoma enhydri, $C$. strumosum, C. villosum.

Acarina: Halarachne miroungae.

\section{ACKNOWLEDGMENTS}

The assistance of Dr. R. L. Rausch, Arctic Health Research Laboratory, Alaska, and S. Prudhoe, British Museum (Natural History), London, with certain questions of nomenclature is gratefully acknowledged.

\section{LITERATURE CITED}

Anderson, R. C.

1959. The taxonomy of Dipetalonema spirocauda (Leidy, 1858) n. comb. (=Skrjabinaria spirocauda) and Dirofilaria roemeri (Linstow, 1905) n. comb. (=Dipetalonema roemeri). Can. J. Zool. 37: 481-493.

Babero, B. B., and L. J. Thomas.

1960. A record of Pharurus oserkaiae (Skrjabin, 1942) in an Alaskan whale. J. Parasitol. 46: 726.

Baer, J. G., H. Miranda C., W. Fernandez R., and J. Medina $\mathrm{T}$,

1967. Human diphyllobothriasis in Peru. Z. Parasitenk. 28: 277-289.

Ball, G. H.

1930. An acanthocephalan, Corynosoma strumosum (Rudolphi), from the California harbor seal. Univ. Calif. Publ. Zool. 33: 301-305.
Banks, N.

1910. New American mites [Arachnoidea, Acarina]. Proc. Entomol. Soc. Wash. 12: 2-12.

Baylis, H. A.

1916. Some ascarids in the British Museum (Natural History). Parasitology 8: 360-378.

1933. A new species of the nematode genus Uncinaria from a sea-lion, with some observations on related species. Parasitology 25: 308-316.

1947. A redescription of Uncinaria lucasi Stiles, a hookworm of seals. Parasitology 38: 160162.

Benson, S. B., and T. C. Groody.

1942. Notes on the Dall porpoise (Phocoenoides dalli). J. Mammal. 23: 41-51.

Brown, D. H., R. W. McIntyre, C. A. Delliquadri, and

R. J. Schroeder.

1960. Health problems of captive dolphins and seals. J. Am. Vet. Med. Assoc. 137: 534-538.

Caballero y C., E., and D. I. Peregrina.

1938. Nemátodos de los mamiferos de México. An. Inst. Biol., México 9: 289-306.

Ching, H. L., and E. S. Robinson.

1959. Two campulid trematodes from a new host, the harbor porpoise. J. Parasitol. 45: 181.

Ciurea, I.

1933. Les vers parasites de l'homme, des mammifères, et des oiseaux provenant des poissons du Danube et de la Mer Noire. Premier mémoire. Trématodes, famille Heterophyidae Odhner, avec un essai de classification des trématodes de la superfamille Heterophyoidea Faust. Arch. Roum. Pathol, Exp. Microbiol. 6: $5-134$.

Cornwall, I. E.

1927. Some North Pacific whale barnacles. Contrib. Can. Biol. Fish., New. Ser. 3: 501-517.

1928. Collecting at Cachalot whaling station. Can. Field - Nat. 42: 9-12.

1955. The barnacles of British Columbia. B.C. Prov. Mus., Dep. Educ., Handb. No. 7, 69 p. Dailey, M. D.

1969. Stictodora ubelakeri a new species of heterophyid trematode from the California sea lion (Zalophus californianus). Bull. South. Calif. Acad. Sci. 68: 82-85.

1970. The transmission of Parafilaroides decorus (Nematoda: Metastrongyloidea) in the California sea lion (Zalophus californianus). Proc. Helminthol. Soc. Wash. 37: 215-222.

Dailey, M. D., and B. L. Hill.

1970. A survey of metazoan parasites infecting the California (Zalophus californianus) and Steller (Eumetopias jubatus) sea lion. Bull. South. Calif. Acad. Sci. 69 : 126-132.

Dall, W. H.

1872a. Descriptions of three new species of Crustacea, parasitic on the Cetacea of the N.W. coast of America. Proc. Calif. Acad. Sci. 4: 281-283. [Advance print Nov. 9, 1872.]

$1872 \mathrm{~b}$. On the parasites of cetaceans of the N.W. coast of America, with descriptions of new 
forms. Proc. Calif. Acad. Sci. 4: 299-301. [Advance print Dec. 18, 1872.]

1874. On new parasitic Crustacea from the N.W. coast of America. Proc. Calif. Acad. Sci. 5: 254-255. [Advance print March 3, 1874.]

Delyamure, S. L.

1955. Gel'mintofauna morskikh mlekopitayushchikh $\mathrm{v}$ svete ikh ekologii i filogenii. Izd. Akad. Nauk SSSR, Moscow, 517 p. [English transl. by M. Raveh. 1968. Helminthofauna of marine mammals (ecology and phylogeny). Israel Program for Scientific Translations, Jerusalem, 552 p.]

Doetschman, W. H.

1941. The occurrence of mites in pinnipeds, including a new species from the California sea lion, Zalophus californianus. J. Parasitol. 27 (Dec. suppl.) : 23.

1944a. A new species of endoparasitic mite of the family Halarachnidae (Acarina). Trans. Am. Microsc. Soc. 63: 68-72.

1944b. Notes on Anoplura infesting marine carnivores. J. Parasitol. 30: 200.

Dollfus, R. Ph.

1964. A propos de la récolte, a Banyuls d'un cystique de cestode chez Tursiops truncatus (Montagu, 1821). Les cystiques de cestodes chez les cétacés et pinnipèdes. Vie et Milieu, Suppl. No. 17, p. 177-204.

Dougherty, E. C.

1943a. Notes on the lungworms of porpoises and their occurrence on the California coast. Proc. Helminthol. Soc. Wash. 10: 16-22.

1943b. The genus Filaroides van Beneden, 1858, and its relatives: preliminary note. Proc. Helminthol. Soc. Wash. 10: 69-74.

1943c. The lungworms of porpoises: a correction. Proc. Helminthol. Soc. Wash. 10: 74-75.

1944. The lungworms (Nematoda: Pseudaliidae) of the Odontoceti. Part I. Parasitology 36: 80-94.

1946. The genus Aelurostrongylus Cameron, 1927 (Nematoda: Metastrongylidae), and its relatives; with descriptions of Parafilaroides, gen. nov., and Angiostrongylus gubernaculat$u s$, sp. nov. Proc. Helminthol. Soc. Wash. 13: 16-25.

1949. The phylogeny of the nematode family Metastrongylidae Leiper, [1909]: a correlation of host and symbiote evolution. Parasitology 39: 222-234.

1951. A further revision in the classification of the family Metastrongylidae Leiper [1909] (phylum Nematoda). Parasitology 41: 91-96.

Dougherty, E. C., and C. M. Herman.

1947. New species of the genus Parafilaroides Dougherty, 1946 (Nematoda: Metastrongylidae), from sea-lions, with a list of the lungworms of the Pinnipedia. Proc. Helminthol. Soc. Wash. 14: 77-87.
Ewing, H. E.

1923. New genera and species of sucking lice. J. Wash. Acad. Sci. 13: 146-149.

Faust, E. C.

1937. Mammalian heart worms of the genus $\mathrm{Di}$ rofilaria. Festschr. Bernhard Nocht zum 80 Geburtstag, p. 131-139. Hamburg.

Fay, F. H.

1960. Carnivorous walrus and some arctic zoonoses. Arctic 13: 111-122.

Ferris, G. F.

1916. Anoplura from sea-lions of the Pacific Ocean. Entomol. News 27: 366-370.

1925. On two species of the genus Halarachne (Acarina, Gamasidae). Parasitology 17: 163167.

1934. Contributions toward a monograph of the sucking lice. Pt. 7. Stanford Univ. Publ., Univ. Ser., Biol. Sci. 2: 471-526.

1942. Observations on some ectoparasitic mites (Arachnida:Acarina:Dermanyssidae). Microentomology 7: 77-83.

1951. The sucking lice. Mem. Pac. Coast Entomol. Soc. 1: 1-320.

Fisher, H. D.

1952. The status of the harbour seal in British Columbia, with particular reference to the Skeena River. Fish. Res. Board Can., Bull. 93, 58 p.

Fleischman, R. W., and R. A. Squire.

1970. Verminous pneumonia in the California sea lion (Zalophus californianus). Pathol. Vet. 7: 89-101.

Flores-Barroeta, L., E. Hidalgo-Escalante, and

R. Oleac.

1961. Nematodes from birds and mammals. IV(1). Erratic parasitosis in Zalophus californianus from Asuncion Island, Baja California, Mexico. Helminthologia 3: 112116.

Golvan, Y. J.

1959. Acanthocéphales de genre Corynosoma Lühe, 1904 parasites de mammifères d'Alaska et de Midway. Ann. Parasitol. Hum. Comp. 34: 288-321.

Herman, C. M.

1942. The effect of higueronia on nematodes and nemathelmintic gastric ulcers of California sea lions. Rev. Med. Trop. Parasitol., Bacteriol., Clinica y Lab., 8: 45-47.

Hilliard, D. K.

1960. Studies on the helminth fauna of Alaska. XXXVIII. The taxonomic significance of eggs and coracidia of some diphyllobothriid cestodes. J. Parasitol. 46: 703-716.

Hurley, D. E., and J. L. Mohr.

1957. On whale-lice (Amphipoda: Cyamidae) from the California gray whale, Eschrichtius glaucus. J. Parasitol. 43: 352-357.

Jellison, W. J.

1952. Anoplura from mammals of the Pribilof Islands. J. Parasitol. 38: 274-275. 
Jellison, W. L., and K. A. Neiland.

1965. Parasites of Alaskan vertebrates. Hostparasite index. Univ. Okla. Res. Inst., Norman, Okla., Proj. 1508, 73 p. (Mimeographed.)

Johnson, M. L., C. H. Fiscus, B. T. Ostenson, and

M. L. Barbour.

1966. Marine Mammals. In N. J. Wilimovsky, (editor), Environment of the Cape Thompson Region, Alaska, p. 877-924. U.S. Atomic Energy Commission, Division of Technical Information.

Johnston, D. G., and S. H. Ridgway.

1969. Parasitism in some marine mammals. J. Am. Vet. Med. Assoc. 155: 1064-1072.

Johnston, T. H., and P. M. Mawson.

1945. Parasitic nematodes. B.A.N.Z. (British, Australian and New Zealand) Antarctic Research Expedition 1929-1931, Rep.-Ser. B, 5: (Part 2) 73-159.

Kagei, N.

1969. [Life history of nematodes of the genus Anisakis.] (In Japanese.) Saishin-Igaku [Advances in Medical Sciences] 24: 389-400.

Kagei, N., T. Oshima, and A. Takemura.

1967. [Survey of Anisakis spp. (Anisakinae, Nematoda) in marine mammals on the coast of Japan.] (In Japanese, English summary.) Jap. J. Parasitol. 16: 427-435.

Kellogg, V. L., and G. F. Ferris.

1915. The Anoplura and Mallophaga of North American mammals. Stanford Univ. Publ., Univ. Ser. (1915), p. 1-74.

Kenyon, K. W.

1961. Cuvier beaked whales stranded in the Aleutian Islands. J. Mammal. 42: 71-76.

1962. Notes on phocid seals at Little Diomede Island, Alaska. J. Wildl. Manage. 26: 380387.

1969. The sea otter in the eastern Pacific Ocean. North Am. Fauna, No. 68, 352 p.

Kenyon, K. W., C. E. Yunker, and I. M. Newell.

1965. Nasal mites (Halarachnidae) in the sea otter. J. Parasitol. 51: 960.

Keyes, M. C.

1965. Pathology of the northern fur seal. J. Am. Vet. Med. Assoc. 147: 1090-1095.

Kreis, H. A.

1938. Beiträge zur Kenntnis parasitischer Nematoden. VI. Parasitische Nematoden aus dem Zoologischen Garten in Bäsel. Zentralb. Bakteriol., Abt. 1, Orig. 141: 279-304.

1940. Beiträge zur Kenntnis parasitischer Nematoden. IX. Parasitische Nematoden aus dem Naturhistorischen Museum Bäsel. Zentralb. Bakteriol., Abt. 1, Orig. 145: 163-208.

Kruidenier, F. J.

1954. A seal host of the acanthocephalan Corynosoma: correction. J. Parasitol. 40: 363-364.

Leidy, J.

1886. Notices of nematoid worms. Proc. Acad. Nat. Sci. Philadelphia, Ser. 3, 38: 308313.
Leung, Y. M.

1965. A collection of whale-lice (Cyamidae: Amphipoda). Bull. South. Calif. Acad. Sci. 64: 132-143.

1967. An illustrated key to the species of whalelice (Amphipoda, Cyamidae), ectoparasites of Cetacea, with a guide to the literature. Crustaceana 12: 279-291.

1970. First record of the whale-louse genus Syncyamus (Cyamidae: Amphipoda) from the western Mediterranean, with notes on the biology of odontocete cyamids. In G. Pilleri (editor), Investigations on Cetacea 2: 243247. University of Berne, Switzerland.

Lincicome, D. R.

1943. Acanthocephala of the genus Corynosoma from the California sea-lion. J. Parasitol, 29: 102-106.

Lütken, C. F.

1887. Tillaeg til "Bidrag til Kundskab om Arterne of Slaegten Cyamus Latr. eller Hvallusene.” K. Dan. Vidensk. Selsk. Skr., Ser. 6, 4: $316-322$.

Lyster, L. L.

1940. Parasites of some Canadian sea mammals. Can. J. Res., D, 18: 395-409.

Margolis, L.

1954a. List of the parasites recorded from sea mammals caught off the West Coast of North America. J. Fish. Res. Board Can. 11: 267281.

1954b. Three kinds of whale-lice (Cyamidae: Amphipoda) from the Pacific coast of Canada, including a new species. J. Fish. Res. Board Can. 11: 319-325.

1955a. Notes on the morphology, taxonomy and synonomy of several species of whale-lice $(\mathrm{Cy}$ amidae; Amphipoda). J. Fish. Res. Board Can. 12: 121-133.

1955b. Corynosoma hadweni Van Cleave, a probable synonym of $C$. wegeneri Heinze (Acanthocephala). J. Parasitol. 41: 326-327.

1956. Parasitic helminths and arthropods from Pinnipedia of the Canadian Pacific coast. J. Fish. Res. Board Can. 13: 489-505.

1959. Records of Cyamus balaenopterae Barnard and Neocyamus physeteris (Pouchet), two species of whale lice (Amphipoda), from the northeast Pacific. Can. J. Zool. 37: 895-897.

Margolis, L., and G. C. Pike.

1955. Some helminth parasites of Canadian $\mathrm{Pa}$ cific whales. J. Fish. Res. Board Can. 12: 97120.

Markowski, S.

1952. The cestodes of pinnipeds in the Arctic and other regions. J. Helminthol. 26: 171-214.

Martin, W. E., C. K. Haun, H. S. Barrows, and

H. Cravioto.

1970. Nematode damage to brain of striped dolphin, Lagenorhynchus obliquidens. Trans. Am. Microsc. Soc. 89: 200-205. 
McAtee, W. L.

1923. Anoplura. In A biological survey of the Pribilof Islands, Alaska. North Am. Fauna, No. $46,142$.

Mozgovoy, A. A.

1951. Ascaridaty mlekopitayushchikh SSSR (Anisakoidea). [The Ascaridata of mammals in the USSR (Anisakoidea).] Tr. Gel'mintol. Lab. Akad. Nauk SSSR 5: 14-22.

1953. Ascaridaty zhivotnykh i cheloveka i vyzyvaemye imi zabolevaniya. [Ascaridata of animals and man and the diseases caused by them.] Osn. Nematodologii, Vol. 2, Part 2. Izd. Akad. Nauk SSSR, Moscow, 616 p.

Mueller, J. F.

1927a. The excretory system of Anisakis simplex. J. Parasitol. 13: 222.

1927b. The excretory system of Anisakis simplex. Z. Wiss. Biol., Abt. B, Z. Zellforsch. Mikrosk. Anat. 5: 495-504.

Myers, B. J.

1959. Phocanema, a new genus for the anisakid nematode of seals. Can. J. Zool. 37: 459465.

Neiland, K. A.

1961. Suspected role of parasites in non-rookery mortality of fur seals (Callorhinus ursinus). J. Parasitol. 47: 732.

1962. Alaskan species of acanthocephalan genus Corynosoma Luehe, 1904. J. Parasitol. 48: 69-75.

Neiland, K. A., D. W. Rice, and B. L. Holden.

1970. Helminths of marine mammals, I. The genus Nasitrema, air sinus flukes of delphinid Cetacea. J. Parasitol. 56: 305-316.

Newell, I. M.

1947. Studies on the morphology and systematics of the family Halarachnidae Oudemans 1906 (Acari, Parasitoidea). Bull. Bingham Oceanogr. Collect. 10: 235-266.

Nybelin, O.

1931. Säugetier- und Vogelcestoden von Juan Fernandez. Nat. Hist. Juan Fernandez and Easter Island 3: 493-523.

Olsen, O. W.

1958. Hookworms, Uncinaria lucasi Stiles, 1901, in fur seals, Callorhinus ursinus (Linn.), on the Pribilof Islands. Trans. Twenty-third North Am. Wildl. Conf., p. 152-175.

Olsen, O. W., and E. T. Lyons.

1962. Life cycle of the hookworm, Uncinaria lucasi Stiles, of northern fur seals, Callorhinus ursinus, on the Pribilof Islands in the Bering Sea. J. Parasitol. 48 (2, Sect. 2) : 42-43.

1965. Life cycle of Uncinaria lucasi Stiles, 1901 (Nematoda: Ancylostomatidae) of fur seals, Callorhinus ursinus Linn., on the Pribilof Islands, Alaska. J. Parasitol. 51: 689700 .

Osborn, H.

1899. List of insects hitherto known from the Pribilof Islands IX. Acarina. In D. S. Jordan.
The fur seals and fur-seal islands of the North Pacific Ocean, Part 3, p. 553-554.

Oudemans, A. C.

1916. Acarologische aanteekeningen, LX. Entomol. Ber., Amsterdam, (91), 4: 308-316.

1926. Halarachne-Studien. Arch. Naturgesch., Abt. A, 91: 48-108.

Perry, M. L.

1967. A new species of Dipetalonema from the California sea lion and a report of microfilariae from a Steller sea lion (Nematoda: Filarioidea). J. Parasitol. 53: 1076-1081.

Price, E. W.

1932. The trematode parasites of marine mammals. Proc. U.S. Natl. Mus. 81: 1-68.

Rausch, R.

1953. Studies on the helminth fauna of Alaska. XIII. Disease in the sea otter, with special reference to helminth parasites. Ecology 34: 584-604.

Rausch, R., B. B. Babero, R. V. Rausch, and E. L. Schiller.

1956. Studies on the helminth fauna of Alaska. XXVII. The occurrence of larvae of Trichinella spiralis in Alaskan mammals. J. Parasitol. 42: 259-271.

Rausch, R., and B. Locker.

1951. Studies on the helminth fauna of Alaska. II. On some helminths parasitic in the sea otter, Enhydra lutris (L.). Proc. Helminthol. Soc. Wash. 18: 77-81.

Rausch, R. L.

1964. Studies on the helminth fauna of Alaska. XLI. Observations on cestodes of the genus Diplogonoporus Lönnberg, 1892 (Diphyllobothriidae). Can. J. Zool. 42: 1049-1069.

Rausch, R. L., and F. H. Fay.

1966. Studies on the helminth fauna of Alaska. XLIV. Revision of Ogmogaster Jägerskiöld, 1891 , with a description of $O$. pentalineatus sp. n. (Trematoda: Notocotylidae). J. Parasitol. 52: $26-38$.

Rausch, R. L., and D. K. Hilliard.

1970. Studies on the helminth fauna of Alaska. XLIX. The occurrence of Diphyllobothrium latum (Linnaeus, 1758) (Cestoda: Diphyllobothriidae) in Alaska, with notes on other species. Can. J. Zool. 48: 1201-1219.

Rausch, R. L., and D. W. Rice.

1970. Ogmogaster trilineatus sp. n. (Trematoda: Notocotylidae) from the fin whale, Balaenoptera physalus L. Proc. Helminthol. Soc. Wash. 37: 196-200.

Rice, D. W.

1963. Progress report on biological studies of the larger Cetacea in the waters off California. Nor. Hvalfangst-Tid. No. 7, p. 181187.

Rice, D. W., and V. B. Scheffer.

1968. A list of marine mammals of the world. U.S. Fish Wildl. Serv., Spec. Sci. Rep. Fish. 579, 16 p. 
Ridgway, S. H.

1966. Dall porpoise, Phocoenoides dalli (True): observations in captivity and at sea. Nor. Hvalfangst-Tid. No. 5, p. 97-110.

Ridgway, S. H., and D. G. Johnston.

1965. Two interesting disease cases in wild cetaceans. Am. J. Vet. Res. 26: 771-775.

Scammon, C. M.

1874. The marine mammals of the north-western coast of North America, described and illustrated: together with an account of the American whale-fishery. John H. Carmany and Company, San Francisco, Calif., 319 p. [Facsimile edition, 1969, Manessier Publishing Co., Riverside, Calif.]

Scheffer, V. B.

1939. Organisms collected from whales in the Aleutian Islands. Murrelet 20: 67-69.

1945. Growth and behavior of young sea lions. J. Mammal. 26: 390-392.

Scheffer, V. B., and J. W. Slipp.

1944. The harbour seal in Washington State. Am. Midland Nat. 32: 373-416.

1948. The whales and dolphins of Washington State with a key to the cetaceans of the west coast of North America. Am. Midland Nat. 39: 257-337.

Schiller, E. L.

1954. Studies on the helminth fauna of Alaska. XVII. Notes on the intermediate stages of some helminth parasites of the sea otter. Biol. Bull. 106: 107-121.

1959. Observations on the morphology and life cycle of Microphallus pirum (Afanas'ev, 1941). Trans. Am. Microsc. Soc. 78: 65-76.

Schroeder, C. R., and H. M. Wegeforth

1935. The occurrence of gastric ulcers in sea mammals of the California coast, their etiology and pathology. J. Am. Vet. Med. Assoc., 87, N.S., 40 : 333-342.

Skrjabin, K. I.

1944. On trematodes of the genus Odhneriella Skrjabin, 1915, parasitic of sea mammals. Comptes Rend. (Doklady) Acad. Sci. URSS 44: 302-303.

Skrjabin, K. I., and N. P. Shikhobalova.

1948. Filyarii zhivotnykh i cheloveka. [Filariae of animals and man.] Sel'khozgiz, $608 \mathrm{p}$.

Skrjabin, K. I., N. P. Shikhobalova, and A. A.

Mozgovoy.

1951. Oksiuraty i Askaridaty. [Oxyurata and Ascaridata.] Opredelitel' Paraziticheskikh Nematod, Vol. 2. Izdat. Akad. Nauk SSSR, Moscow, $631 \mathrm{p}$.

Skrjabin, K. I., N. P. Shikhobalova, R. S. Shult's,

T. I. Popova, S. N. Boev, and S. L. Delyamure.

1952. Strongilyaty. Opredelitel' Paraziticheskikh Nematod, Vol. 3. Izdat. Akad. Nauk SSSR, Moscow, 890 p. (English transl. by A. Birron and Z. S. Cole. 1961. Strongylata. Key to Parasitic Nematodes, Vol. 3. Israel
Program for Scientific Translations, Jerusalem, 890 p.)

Steding, E.

1923. Zur anatomie und histologie von Halarachne otariae $\mathrm{n}$. sp. Z. Wiss. Zool. 121: 442493.

Stiles, C. W.

1901. Uncinariosis (anchylostomiasis) in man and animals in the United States. Texas Med. News 10: 523-532.

Stiles, C. W., and A. Hassall.

1899. Internal parasites of the fur seal. In D. S. Jordan. The fur seals and fur-seal islands of the North Pacific Ocean, Part 3, p. 99-177.

Stunkard, H. W.

1948. Pseudophyllidean cestodes from Alaskan pinnipeds. J. Parasitol. 34: 211-228.

Stunkard, H. W., and C. H. Alvey.

1929. A new liver fluke, Zalophotrema hepaticum, from the California sea lion, Zalophus californianus. J. Parasitol. 16: 106-107.

1930. The morphology of Zalophotrema hepaticum, with a review of the trematode family Fasciolidae. Parasitology 22: 326-333.

Stunkard, H. W., and H. W. Schoenborn.

1936. Notes on the structure, distribution and synonymy of Diphyllobothrium lanceolatum. Am. Mus. Novit., No. 880, 1-9.

Tadros, G.

1966. A collection of helminths from mammals, birds and reptiles. J. Vet. Sci. U.A.R., 3: 101110.

Taylor, A. E. R., D. H. Brown, D. Heyneman, and

R. W. McIntyre.

1961. Biology of filarioid nematode Dipetalonema spirocauda (Leidy, 1858) from the heart of captive harbor seals and sea lions, together with pathology of the hosts. J. Parasitol. 47: 971-976.

Thorsteinson, F. V., and C. J. Lensink.

1962. Biological observations of Steller sea lions taken during an experimental harvest. J. Wildl. Manage. 26: 353-359.

Van Cleave, H. J.

1953a. A preliminary analysis of the acanthocephalan genus Corynosoma in mammals of North America. J. Parasitol. 39: 1-13.

1953b. Acanthocephala of North American mammals. Illinois Biol. Monogr. 23: 1-179.

Wardle, R. A., J. A. McLeod, and I. E. Stewart.

1947. Lühe's "Diphyllobothrium" (Cestoda). J. Parasitol. 33: 319-330 .

Weber, N. A.

1950. A survey of the insects and related arthropods of Arctic Alaska. Part I. Trans. Am. Entomol. Soc. 76: 147-206.

Williams, H. H.

1968. The taxonomy, ecology and host-specificity of some Phyllobothriidae (Cestoda: Tetraphyllidea), a critical revision of Phyllobothrium Beneden, 1849 and comments on some al- 
lied genera. Philos. Trans. R. Soc. London, Ser. B, Biol. Sci. 253: 231-307.

Wolfgang, R. W.

1956. Dochmoides yukonensis sp. nov. from the brown bear (Ursus americanus) in the Yukon. Can. J. Zool. 34: 21-27.

\section{Yamaguti, S.}

1951. Studies on the helminth fauna of Japan. Part 45. Trematodes of marine mammals. Arb. Med. Fak. Okayama 7: 283-294. 


\section{$2 \mathrm{BHL}$ Biodiversity Heritage Library}

Margolis, L and Dailey, Murray D. 1972. "Revised annotated list of parasites from sea mammals caught off the west coast of North America." NOAA technical report NMFS SSRF 647, 1-23. https://doi.org/10.5962/bhl.part.23513.

View This Item Online: https://www.biodiversitylibrary.org/item/38897

DOI: https://doi.org/10.5962/bhl.part.23513

Permalink: https://www.biodiversitylibrary.org/partpdf/23513

\section{Holding Institution}

MBLWHOI Library

\section{Sponsored by}

MBLWHOI Library

\section{Copyright \& Reuse}

Copyright Status: NOT_IN_COPYRIGHT

This document was created from content at the Biodiversity Heritage Library, the world's largest open access digital library for biodiversity literature and archives. Visit BHL at https://www.biodiversitylibrary.org. 